\title{
Isolation, Characterization and Antibacterial Activities of Lactic Acid Bacteria Isolated From Batak's Special Food "Dali Ni Horbo"
}

\section{Isolasi, Karakterisasi dan Aktivitas Antibakteri Bakteri Asam Laktat yang Diisolasi dari Makanan Khas Batak "Dali Ni Horbo"}

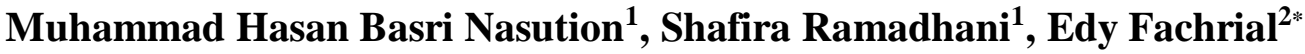 \\ ${ }^{1}$ Fakultas Kedokteran, Program Studi Pendidikan Dokter, Universitas Prima Indonesia, \\ Medan, Indonesia 20111-22999 \\ ${ }^{2}$ Laboratorium Biologi Molekuler, Fakultas Kedokteran, Universitas Prima Indonesia, \\ Medan, Indonesia 20111-22999 \\ *Penulis korepondensi, email: fachrial_edy@yahoo.co.id
}

\begin{abstract}
Lactic Acid Bacteria (LAB) are gram-positive bacteria that are rod or round in shape, do not form spores, and do not have cytochromes. LAB can be isolated from fermented food products. LAB is useful to inhibit the growth of pathogenic bacteria so that they are potential antibacterial sources. The purpose of this study was to isolate LAB from the traditional food Dali Ni Horbo, continued with characterization, antimicrobial testing, and sensitivity testing towards several antibiotics. From the results of the study, the number of colonies obtained was $2.4 \times 10^{7} \mathrm{CFU} / \mathrm{mL}$. 6 isolates were randomly selected, coded as isolates UPDH1, UPDH2, UPDH3, UPDH4, UPDH5, UPDH6, respectively. Biochemical characterization showed that the isolates were gram-positive and catalasenegative bacteria. Results of antibiotic sensitivity testing using 6 antibiotics, namely amoxicillin (AML), erythromycin (E), oxacillin (OX), ofloxacin (OFX), cefotaxime (CTX), and gentamicin (CN), showed that all the isolates were resistant to CTX. The UPDH1 isolate was resistant to AML and OX. The UPDH3, UPDH5, and UPDH6 isolates were resistant to AML, and the UPDH4 isolate was resistant to E, OFX, CTX, CN, and OX. Antimicrobial tests used the disk diffusion method against Escherichia coli and Staphylococcus aureus. The UPDH2 isolate, gave an inhibition zone of $6.7 \mathrm{~mm}$, and UPDH5 and UPDH6 gave inhibition zones of $7.6 \mathrm{~mm}$ and $8.5 \mathrm{~mm}$ respectively, against $E$. coli. Microbial inhibition tests against $S$. aureus by UPDH1, UPDH2, UPDH5 and UPDH6 gave inhibition zones of $13.5 \mathrm{~mm}, 9.0 \mathrm{~mm}, 12.1 \mathrm{~mm}$ and $12 \mathrm{~mm}$ respectively. From the results in this research it can be concluded that the traditional food Dali Ni Horbo is a potential source of probiotics.
\end{abstract}

Keywords: Antibiotics, Antimicrobials, Lactic Acid Bacteria.

\begin{abstract}
ABSTRAK
Bakteri Asam Laktat (BAL) adalah bakteri gram positif yang berbentuk batang atau bulat, tidak membentuk spora, dan tidak mempunyai sitokrom. BAL bisa di isolasi dari makanan produk hasil fermentasi. BAL berguna untuk menghambat pertumbuhan bakteri patogen sehinggsa berpotensi sebagai sumber senyawa antibakteri. Tujuan dari penelitian ini adalah mengisolasi BAL dari makanan tradisional Dali Ni Horbo, dilanjutkan dengan mengkarakterisasi, uji antimikroba, dan uji sensitivitas terhadap beberapa antibiotik. Dari hasil penelitian jumlah koloni yang diperoleh yaitu sebanyak 2,4 $\times 10^{7} \mathrm{CFU} / \mathrm{mL}$. 6 isolat dipilih secara acak, dan diberi kode, mulai dari isolat UPDH1, UPDH2, UPDH3, UPDH4, UPDH5, dan UPDH6. Uji karaktersisasi biokimia menunjukkan bahwa kesemua isolat merupakan bakteri gram positif dan katalase negatif. Pada uji sensitivitas antibiotik menggunakan 6 antibiotik, yaitu amoksisilin (AML), eritromisin (E), oksasilin (OX), oflaksasin
\end{abstract}


(OFX), cefotaksim (CTX), dan gentamisin (CN), diperoleh hasil bahwa semua isolat resisten terhadap CTX. Isolat UPDH1 resiten terhadap AML dan OX. Isolat-isolat UPDH3, UPDH5, UPDH6 resisten terhadap AML, dan isolat UPDH4 resisten terhadap E, OFX, CTX, CN, dan OX. Uji antimikroba dilakukan menggunakan metode difusi cakram dan diuji terhadap bakteri Escherichia coli dan Staphylococcus aureus. Pada isolat UPDH2 diperoleh zona hambat 6,7 mm, sedangkan pada isolat UPDH5 dan UPDH6 diperoleh zona hambat 7,6 $\mathrm{mm}$ dan $8,5 \mathrm{~mm}$ terhadap E.coli. Pada uji inhibisi mikroba terhadap S.aureus oleh UPDH1, UPDH2, UPDH5 dan UPDH6, diperoleh zona hambat secara berturut 13,5 mm, $9,0 \mathrm{~mm}, 12,1 \mathrm{~mm}$ dan $12 \mathrm{~mm}$. Dari hasil penelitian ini dapat disimpulkan bahwa makanan tradisional Dali Ni Horbo berpotensi sebagai salah satu sumber probiotik.

Kata Kunci: Antibiotik, Antimikroba, Bakteri Asam Laktat, Dali Ni Horbo.

\section{PENDAHULUAN}

Bakteri Asam Laktat (BAL) tergolong Gram positif dan Gram negatif (Situmeang et al., 2017). Bakteri Asam Laktat (BAL) dapat memproduksi senyawa antimikroba yaitu hidrogen peroksida, asam organik dan bakteriosin yang dapat menghambat pertumbuhan mikroba patogen maupun pembusuk pada bahan pangan, dan juga dapat mengubah waktu simpannya menjadi lebih panjang (Afriani et al., 2017). Secara umum, karakteristik dari BAL adalah Gram positif dan uji katalase adalah negatif (Yanti and Dali, 2013). Genus dari BAL adalah Leuconostoc, Lactobacillus, Enterococcus, Streptococcus, Pediococcus, Lactococcus dan Tetragenococcus (Urnemi et al., 2012). BAL tergolong mikroorganisme status GRAS (Generally Recognized as Safe) yang dapat diaplikasikan sebagai bakteri probiotik (Nur et al., 2015).

Probiotik menurut FAO/WHO adalah organisme hidup, yang bila diberikan dalam jumlah yang terpenuhi dapat memberikan keuntungan pada inangnya (Nur et al., 2015). Dari uji in vitro ditemukan bahwasanya Lactobacillus dapat menghambat beberapa macam bakteri patogen seperti Shigella, Listeria, Staphylococcus, Vibrio, dan Salmonella. Lactobacillus bukan hanya memiliki sifat produksi asam laktat akan tetapi juga memiliki sifat yang antagonis, dan dapat memproduksi beberapa senyawa antibakteri. Contohnya laktosidin, asidolin dan asidofilin yang sangat luas spektrumnya terhadap bakteri Gram positif maupun yang negatif (Sunaryanto et al., 2014).

Bakteri asam laktat bisa di isolasi dari makanan produk berbahan dasar susu mentah (Situmeang et al., 2017). Di Indonesia banyak kita jumpai makanan yang diolah dari susu sapi dan kerbau. Makanan tradisional olahan dari susu kerbau yang ada di Indonesia antara lain Dali Ni Horbo (Sumatera Utara), Dangke (Sulawesi Selatan), Dadih (Sumatera Barat) (Situmeang et al., 2017). Dali Ni Horbo dibuat dengan cara susu dipanaskan menggunakan api kecil hingga mendidih, setelah itu ditambah getah pepaya (papain) sampai terjadilah gumpalan. Gumpalan yang sudah jadi diletakkan ke cetakan untuk membuat Dali Ni Horbo (Nur et al., 2015). Proses 
dari berbahan dasar susu yang difermentasi dapat menjadi sumber senyawa antimikroba yang diperoleh dari BAL (Fachrial, 2018). Dalam makalah ini, peneliti melaporkan hasil penelitian yang bertujuan mengisolasi beberapa koloni bakteri asam laktat dari Dali Ni Horbo, dilanjutkan karakterisasi isolat bakteri meliputi uji antimikroba terhadap bakteri patogen dan uji sensitivitas terhadap beberapa antibiotik.

\section{METODOLOGI PENELITIAN}

\section{Alat dan Bahan:}

Instrumen yang dimanfaatkan pada riset ini terdiri dari erlenmeyer, cawan petri, gelas kimia, gelas ukur, tabung reaksi, spreader, autoklaf, digital, inkubator, rak tabung reaksi, lemari pendingin, laminar air flow, aluminium foil, timbangan analitik, api bunsen, magnetic stirrer, spatula, mikro pipet, pipet tetes, gelas objek, jarum ose, tabung durham, gelas deck. Bahan yang digunakan dalam penelitian ini adalah Dali Ni Horbo, MRS Agar, MRS Broth, minyak emersi, Nutrien Agar, pepton water, akuades, larutan $\mathrm{H}_{2} \mathrm{O}_{2} 3 \%, \mathrm{CaCO}_{3}$, kristal violet, lugol, alkohol 96\%, alkohol $70 \%$.

\section{Prosedur Kerja:}

\section{Isolasi Bakteri Dari Makanan Dali Ni Horbo dan Karakterisasi Biokimia Isolat}

Isolasi bakteri asam laktat dari Dali Ni Horbo dilakukan dengan mula-mula Dali Ni Horbo ditimbang 1 gr dan diletakkan ke dalam media MRS Broth 9 ml di dalam tabung reaksi, kemudian diaduk sampai homogen. Dilakukan inkubasi terhadap hasil yang telah diaduk, pada suhu $37^{\circ} \mathrm{C}$ dengan kondisi anerob di dalam inkubator selama 24 jam. Penelitian ini menggunakan pengenceran bertingkat memakai MRS broth steril $\left(10^{-1}\right.$ sampai $\left.10^{-7}\right)$. $0,1 \mathrm{~mL}$ kultur BAL hasil inkubasi sebelumnya, dimasukkan ke dalam mikrotube $1,5 \mathrm{~mL}$ dan, ditambahkan $0,9 \mathrm{~mL}$ MRS broth, kemudian dihomogenkan memakai cara bolak-balik untuk memperoleh pengenceran $10^{-1}$. Setelah itu alikout $0,1 \mathrm{~mL}$ dari pengenceran $10^{-1}$ dicampurkan $0,9 \mathrm{~mL}$ MRS broth pada tabung mikro lain, dan dihomogenkan lagi dengan cara yang sama, untuk memperoleh pengenceran $10^{-2}$. Proses ini diulangi lagi sampai diperoleh pengenceran $10^{-7}$. Alikuot $0,1 \mathrm{~mL}$ dengan pengenceran akhir disebarkan ke MRS agar, lalu diinkubasi secara anerobik selama 48 jam dengan suhu $37{ }^{\circ} \mathrm{C}$. Dari koloni-koloni yang tumbuh, dipilihnya enam isolat dengan acak dan digoreskan pada MRS agar yang baru. Sebelumnya koloni yang tumbuh dihitung menggunakan alat koloni counter, dan dihitung koloni BAL dengan rumus berikut: (Fachrial, 2018). 


$$
C F U=\text { Total Koloni } B A L \times \frac{1}{\text { pengenceran }} \times \frac{1}{\text { berat sampel }}
$$

Setelah dilakukan pemilihan 6 isolat secara acak, isolat-isolat tersebut diberi kode UPDH1, UPDH2, UPDH3, UPDH4, UPDH5, UPDH6. Pada isolat-isolat ini dilakukan karakterisasi biokimia yang terdiri dari uji tipe fermentasi, uji katalase, dan pewarnaan gram (Fachrial, 2018).

\section{Uji Sensitivitas Antibiotik}

Uji ini dilakukan dengan metode difusi cakram. 1 ose BAL setiap isolat, dikultur dengan $10 \mathrm{ml}$ MRS Broth dengan menggunakan tabung reaksi dan diinkubasi dengan suhu $37{ }^{\circ} \mathrm{C}$ selama 24 jam. Setelah selesai diinkubasi isolat BAL tersebut dioleskan secara merata dengan menggunakan kapas steril ke permukaan MRS Agar dalam cawan petri. Cakram antibiotik yang digunakan terdiri dari enam jenis antibiotik, masing-masing berdiameter $6 \mathrm{~mm}$, yaitu eritromisin (E), amoksisilin (AML), oksasilin (OX), gentamisin (CN), cefotaksim (CTX), dan ofloksasin (OFX). Keenam jenis cakram tersebut diletakkan di permukaan media MRS Agar yang sudah dioleskan BAL dengan menggunakan pinset. Kemudian dilakukan inkubasi dengan suhu $37{ }^{\circ} \mathrm{C}$ selama 48 jam. Setelah selesai diinkubasi, zona hambat pada tumbuhnya BAL diukur dengan jangka sorong (Ulfa et al., 2019).

\section{Uji Antimikroba BAL terhadap Bakteri Patogen}

Uji ini dilakukan dengan metode difusi cakram. BAL yang diuji diinokulasi ke tabung reaksi yang berisi MRS Broth $10 \mathrm{~mL}$ dan diinkubasi pada suhu $37{ }^{\circ} \mathrm{C}$ selama 24 jam. Bakteri patogen (Escherichia coli dan Staphylococcus aureus) dikultur pada Nutrien Agar, yaitu dengan cara mencelupkan kapas steril ke dalam tabung reaksi yang telah berisi bakteri patogen, lalu menggoreskannya secara merata pada Nutrien Agar steril di cawan petri. Nutrien agar dicawan petri yang telah diinokulasi dengan bakteri patogen diinkubasi pada $37{ }^{\circ} \mathrm{C}$ selama 24 jam. Selanjutnya kertas cakram steril (diameter $5 \mathrm{~mm}$ ) dicelupkan ke dalam kultur BAL dalam MRS Broth. Dengan menggunakan pinset, kertas cakram yang telah dicelupkan pada kultur BAL, diletakkan pada media Nutrien Agar di cawan petri yang telah dioleskan bakteri patogen. Cawan petri ini kemudian diletakkan di inkubator dan diinkubasi selama 48 jam. Setelah diinkubasi zona hambat yang terbentuk diukur dengan menggunakan jangka sorong (Fachrial, 2018). 


\section{HASIL DAN PEMBAHASAN}

\section{Isolasi Bakteri Asam laktat dan Karakterisasi Biokimia}

Setelah selesai proses inkubasi dan pengenceran yang bertingkat sebanyak 0,1 mL dengan di inokulasi pada media MRS Agar kemudian diinkubasi selama 48 jam dengan suhu $37^{\circ} \mathrm{C}$ dan diperoleh total isolat yang memiliki jumlah koloni BAL adalah 3,3 x $10^{5} \mathrm{CFU} / \mathrm{mL}$. Gambar hasil isolasi BAL dilihat pada Gambar 1.

Setelah selesai melakukan pemurnian, maka terlihat koloni bakteri asam laktat yang berbentuk bulat, sedikit kecil, atau besar. Agak cembung, tepinya rata, mengkilat, bewarna putih susu, sedikit kekuningan (Urnemi et al., 2012). Sesuai dengan teori yang mengungkapkan bahwa ciri dari koloni adalah bewarna putih hingga kuning, bulat, permukaannya tipis dan meluas dengan tepian mengkilap (Y. W. Putri et al., 2018). Jumlah ini hampir sama yang telah dilakukan oleh (Ulfa et al., 2019) disebutkan bahwa BAL yang telah di isolasi dari naniura dan uji sensitifitas terhadap antibiotik mendapat hasil CFU sebanyak 2,4 x $10^{-7} \mathrm{CFU} / \mathrm{mL}$.

Tabel 1 menunjukkan pewarnaan Gram positif, uji katalase negatif, tipe fermentasi homofermentatif. Pada bakteri yang dapat mempertahakan warna ungu dan tidak bisa luntur dengan menggunakan alkohol itu disebut bakteri Gram positif, apabila tidak dapat mempertahankan warna ungu dengan melakukan pencucian terhadap alkohol maka disebut bakteri Gram negatif (Putri et al., 2018). Bakteri Gram positif mempunyai lapisan peptidoglikan lebih tebal, membran selnya hanya memiliki satu lapis, tidak mempunyai membran luar, pada bakteri gram negatif memiliki dinding sel yang tipis yang terletak antara kedua membran sel yang berlapis.

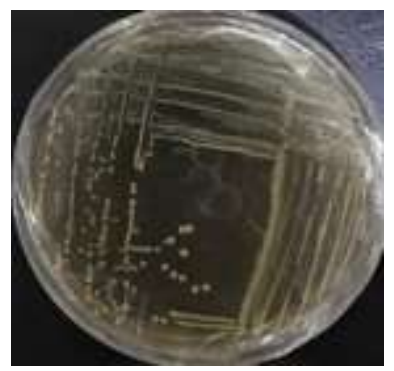

Gambar 1. Koloni Bakteri Asam Laktat

Tabel 1. Hasil Pewarnaan Gram, Uji Katalase, Tipe Fermentasi

\begin{tabular}{cccc}
\hline Isolat Bal & \multicolumn{3}{c}{ Karakteristik Biokimia } \\
\cline { 2 - 4 } & Pewarnaan Gram & Uji katalase & Tipe Fermentatif \\
\hline UPDH1 & Positif & Negatif & Homofermentatif \\
UPDH2 & Positif & Negatif & Homofermentatif \\
UPDH3 & Positif & Negatif & Homofermentatif \\
UPDH4 & Positif & Negatif & Homofermentatif \\
UPDH5 & Positif & Negatif & Heterofermentatif \\
UPDH6 & Positif & Negatif & Homofermentatif \\
\hline
\end{tabular}


Ketika bahwasanya pada saat respirasi, bakteri dipeloreh dari berbagai komponen salah satunya adalah $\mathrm{H}_{2} \mathrm{O}_{2}$. Bakteri dapat memecahkan $\mathrm{H}_{2} \mathrm{O}_{2}$ dengan enzim katalse tersebut maka akan terjadi terbentuknya kerja pertahanan dari toksik $\mathrm{H}_{2} \mathrm{O}_{2}$ yang diperolehnya sendiri. Bakteri katalase positif akan memotong $\mathrm{H}_{2} \mathrm{O}_{2}$ yang akan menjadi $\mathrm{H}_{2} \mathrm{O}$ dan $\mathrm{O}_{2}$ yang dimana parameter membuktikan bahwa terjadinya gelembung-gelembung oksigen. Pada bakteri katalase negatif tidak di dapati adanya gelembung udara, karena saat diberikan $\mathrm{H}_{2} \mathrm{O}_{2}$ tidak terjadi adanya pemecahan pada bakteri sehingga munculnya $\mathrm{O}_{2}$ pada bakteri tersebut (Putri et al., 2018).

Medium NA adalah medium umum yang terdiri dari nutrisi pertumbuhan mikroorganisme, dan tidak membeda-bedakan mikroba yang tumbuh, dan mikroba yang tumbuh disebut mikroorganisme heterotrof. Pada penelitian Putri dan Kusdiyantini (2018), hasil isolasi medium NA dapat menghasilkan 5 isolat dengan sifat koloni yang berbeda (Putri and Kusdiyantini, 2018).

Pada penelitian ini, semua isolat dapat melewati tahapan pengujian asam, dan didapatkan nilai $\mathrm{pH} 3,86$, oleh karena itu dapat disimpulkan bahwa terjadi akumulasi asam laktat sedikit tinggi pada bahan sampel makanan awal (Dali Ni Horbo) sebagai aktivitas fermentasi. Metode isolasi BAL ini memakai metode spread plate, setelah itu dilakukan pemurnian memakai metode streak plate untuk mengetahui koloni terpisah. Asam laktat dapat diproduksi oleh BAL, yang dapat mengikat $\mathrm{CaCO}_{3}$ menjadi Ca-laktat yang larut, sehingga menyebabkan terjadinya zona bening. Pembentukkan zona bening tersebut dapat menjadi penanda terdapatnya koloni BAL (Nudayanto and Zubaidah, 2015)

\section{Uji Sensitivitas Antibiotik}

Uji ini dilakukan menggunakan metode difusi cakram. Antibiotik yang digunakan pada penelitian ini terdiri atas 6 macam yaitu amoksisilin (AML), eritromisin (E), oksasilin (OX), ofloksasin (OFX), cefotaksim (CTX), dan gentamisin $(\mathrm{CN})$. Hasil dari penelitian pada uji sensitivitas antibiotik ditunjukkan pada Tabel 2 dan Gambar 2.

Tabel 2. Hasil Uji Sensitivitas Antibiotik

\begin{tabular}{ccccccc}
\hline Isolat & \multicolumn{5}{c}{ Zona hambat $(\mathrm{mm})$} \\
\cline { 2 - 6 } & AML & CN & OX & E & OFX & CTX \\
\hline UPDH1 & 0 & $16,6 \mathrm{~mm}$ & 0 & $20,8 \mathrm{~mm}$ & $21,9 \mathrm{~mm}$ & 0 \\
UPDH2 & $12,4 \mathrm{~mm}$ & $18,4 \mathrm{~mm}$ & $16,3 \mathrm{~mm}$ & $16,7 \mathrm{~mm}$ & $16,2 \mathrm{~mm}$ & 0 \\
UPDH3 & 0 & $10,41 \mathrm{~mm}$ & $17,8 \mathrm{~mm}$ & $16,7 \mathrm{~mm}$ & $20,7 \mathrm{~mm}$ & 0 \\
UPDH4 & $5.5 \mathrm{~mm}$ & 0 & 0 & 0 & 0 & 0 \\
UPDH5 & 0 & $13,4 \mathrm{~mm}$ & $11,9 \mathrm{~mm}$ & $20,95 \mathrm{~mm}$ & $8,1 \mathrm{~mm}$ & 0 \\
UPDH6 & 0 & $12,92 \mathrm{~mm}$ & $10,2 \mathrm{~mm}$ & $22,9 \mathrm{~mm}$ & $9,9 \mathrm{~mm}$ & 0 \\
\hline
\end{tabular}



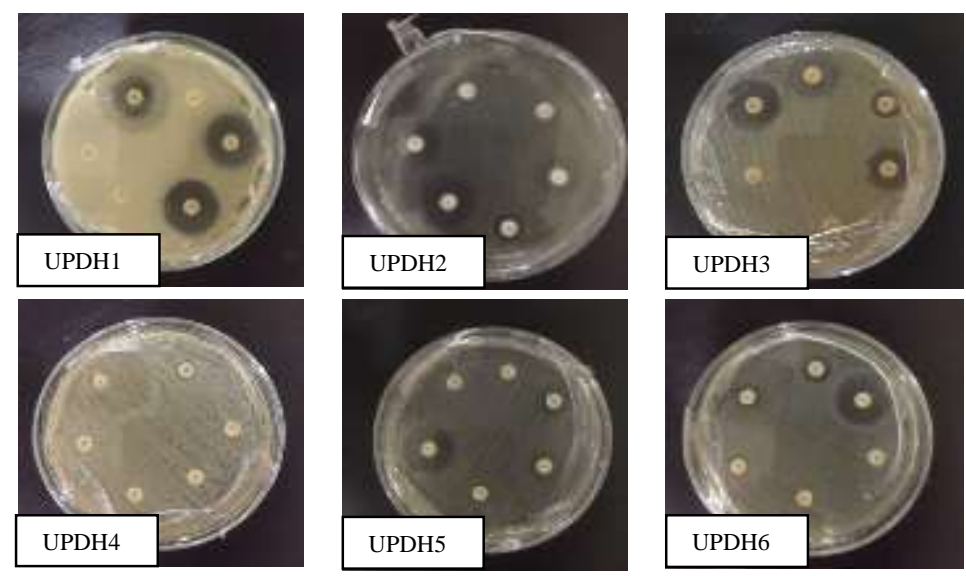

Gambar 2. Hasil Uji Sensitivitas Antibiotik (UPDH1, UPDH2, UPDH3, UPDH4, UPDH5, UPDH6)

Dari hasil uji sensitivitas antibiotik didapatkan bahwa bakteri sensitif terhadap gentamisin. ofloksasin, dan eritromisin. Dalam penelitian bahwa yang terdapat bakteri resistensi terhadap antibiotik tersebut disebabkan mutasi gen spontan (gagal melakukan transfer) atau juga gen horizontal. Ada beberapa mekanisme yang terdapat pada transfer gen horizontal, terdiri dari konjugasi, transformasi dan transduksi (Ulfa et al., 2019). Gentamisin merupakan golongan dari aminoglikosida yang paling sering digunakan pada bakteri gram negatif. Gentamisin memiliki efek terhadap saraf otak yang bersifat nefrotoksik dan neurotoksik (Lintong et al., 2012). Dalam penelitian yang lain dilaporkan oleh (Agustina et al., 2019) masih memiliki hasil yang sama, dimana antibiotik sensitif terhadap ofloksasin. Amoksisilin didapati hasil yang resisten terhadap antibiotik tersebut. Penelitan ini bahwa isolat E.coli 2A, 3A, dan 4A adalah isolat E.coli resisten terhadap amoksisilin (Nugraha et al., 2013). Penelitian lain yang telah di uji bahwa isolat E.coli resisten terhadap amoksisilin, dimana secara keseluruhan BAL sensitif terhadap amoksisilin (Ulfa et al., 2019). Adanya resisten terhadap antibiotik disebabkan karena pengobatan pada pasien tidak adekuat dan terjadinya suatu antimikroba yang resisten terhadap antibiotik dikarenakan proses genetik dan non-genetik (Artati et al., 2016). Amoksisilin merupakan golongan dari antibiotik beta laktam yang artinya dapat memberhentikan campuran dinding sel bakteri (Ulfa et al., 2019). Hasil dari sensitivitas yang memiliki hasil intermediate adalah cefotaksim, yang artinya terletak antara sensitif hingga menuju resisten (Artati et al., 2016). Terdapat hasil cefotaksim berdiameter $0 \mathrm{~mm}$ yang artinya intermediate (Ulfa et al., 2019). Penelitian ini dilakukan bahwa bakteri E.coli sensitif terhadap cefotaksim (Nugraha et al., 2013).

Amoksisilin dapat menghentikan hubungan silang antara cincin polimer peptidoglikan linear menghasilkan komponen utama pada dinding sel bakteri Gram positif. Amoksisilin paling efektif digunakan Gram positif, terdapat beberapa 
bakteri Gram positif terdegradasi amoksisilin yaitu Streptococcus spp, Streptococcus pneumonia, Stapylococcus aureus dan Enterococcus faecalis. Sedangkan pada Gram negatif terdegradasi terdiri dari Escherichia coli, Salmonella spp, Neisseria gonorrhoeae, Proteus mirabilis (Sumampouw, 2018).

Ciprofloksasin yaitu agen antimikroba bisa mengobati beberapa infeksi dikarenakan terhadap E.coli, Klebsiella pneumoniae, S. saprophyticus, Streptococcus pneumoniae, S.aureus dan Salmonella typhi (Sumampouw, 2018).

\section{Uji Antimikroba BAL Terhadap Bakteri Patogen}

Uji antimikroba ini dilakukan dengan menggunakan metode difusi cakram. Pada uji ini dilakukan terhadap 2 bakteri patogen yaitu Escherichia coli dan Staphylococcus aureus. Hasil dari uji antimikroba ditunjukkan pada Tabel 3

Hubungan antara BAL yang dapat mengeluarkan pada senyawa aktif atau enzim hidrolitik, usia pada biakan bakteri, lamanya inkubasi, dan dapat menyebabkan kematian akibat dari asal media nutrisi sehingga zona hambat terjadi (Situmeang et al., 2017). Terdapat ada empat kelompok aktivitas zona hambat: lemah (<5 mm), sedang $(5-10 \mathrm{~mm})$, sangat kuat (> 20-30 mm). Dapat diperoleh dengan hasil yang berbeda, bahwasanya E.coli lebih peka daripada S.aureus. apabila zona bening semakin terbentuk maka penghambatan bakteri asam laktat terhadap E.coli semakin besar juga aktivitasnya (Ismail et al., 2017). Dalam penelitian yang telah dilakukan ini mengungkapkan bahwa S.aureus lebih peka daripada E.coli. S.aureus pada dasarnya lebih peka terhadap BAL, menurut Fachrial mengungkapkan bahwa S.aureus lebih peka dari pada E.coli karena S.aureus pada dasarnya lebih peka terhadap BAL dibandingkan dengan E.coli (Fachrial, 2018).

Pada senyawa antimikroba dari BAL, zona bening berupa dengan batas tepi lingkaran jelas dan tegas dikarenakan ada melakukan aktivitas senyawa bakteriosin, karena bakteriosin terdapat karakteristik single hit inactivation yaitu satu molekul bakteriosin bisa membunuh satu sel bakteri indikator (Kiti et al., 2019).

Pada E.coli yaitu bakteri Gram negatif resisten pada beberapa antibakteri terjadi karena ada tiga lapisan dinding sel terdapat bakteri tersebut, maka beberapa senyawa tidak dapat mengganggu jaringan dari dinding sel bakteri E.coli. Apabila terdapat mikroba tumbuh maka tampak keruh, semakin besar zona bening hendak semakin kuat daya hambat bakteriosin. Pada zona bening fragmen bakteriosin dan ekstrak bakteriosin kode UWH10, UWH1, UWH2, UWH9 dan UWH8 rata - rata dikelompokkan dengan ukuran zona hambat yang berdiameter 5-10 mm (Sidabutar et al., 2013).

Pada uji aktivitas fragmen bakteriosin dan ekstrak bakteriosin diperoleh hasil zona bening dan zona keruh, salah satunya suatu isolat UWH8 terhadap bakteri $P$. stutzeri, V. alginolyticus dan A. hydrophila. 
Tabel 3. Hasil Uji Antimikroba Bakteri Asam Laktat terhadap Bakteri Patogen

\begin{tabular}{ccc}
\hline Sampel & \multicolumn{2}{c}{ Zona hambat $(\mathrm{mm})$} \\
\cline { 2 - 3 } & E.coli & S.aureus \\
\hline UPDH1 & - & $13,5 \mathrm{~mm}$ \\
UPDH2 & $6,7 \mathrm{~mm}$ & $9,0 \mathrm{~mm}$ \\
UPDH3 & - & - \\
UPDH4 & - & - \\
UPDH5 & $7,6 \mathrm{~mm}$ & $12,1 \mathrm{~mm}$ \\
UPDH6 & $8,5 \mathrm{~mm}$ & $12 \mathrm{~mm}$ \\
\hline
\end{tabular}

Terbentuknya zona bening mempunyai dalam arti yang memiliki hambatan pada aktivitas bakteriosin. Sedangkan pada zona keruh menunjukkan bahwa bakteri patogen resisten terhadap bakteriosin sehingga mengakibatkan bakteriosin tidak dapat menghambat aktivitas bakteri patogen dikarenakan konsentrasi pada pemberian bakteriosin tidak sama, yang artinya dimana jumlah sel pada bakteri patogen lebih sedikit, jenis pada bakteri, dan waktu inkubasi (Sidabutar et al., 2013).

Bakteriosin adalah substrat memiliki karakteristik alami protein, maka lebih peka pada aktivitas enzim proteolitik, terdiri dari papain dan proteinase-K. Ada empat isolat BAL memiliki aktivitas antimikroba kemudian ditangkap oleh produksi bakteriosin kearah uji sensitivitas BAL pada aktivitas enzim proteolitik. Bahwa pada senyawa antibakteri, bakteriosin mempunyai sifat yang lebih peka pada enzim proteolitik, dikarenakan mengalami inaktivasi sempurna atau berkurang secara drastis setelah diberinya enzim proteinase-K, pronase dan tripsin (Kusmarwati et al., 2014).

\section{SIMPULAN}

Bakteri Asam Laktat yang di isolasi dari makanan tradisional Dali Ni Horbo mempunyai karakteristik antara lain Gram staining positif, uji katalase negatif, dan tipe fermentasi heterofermentatif. Isolat UPDH3, UPDH5, UPDH6 resisten terhadap amoksisilin dan isolat UPDH4 resisten terhadap eritromisin, ofloksasin, cefotaksim, gentamisin dan oksasilin. Isolat UPDH2 dan UPDH3 sensitif terhadap amoksisilin. Isolat UPDH1, UPDH2, UPDH3, UPDH5, UPDH6 sensitif terhadap gentamisin. Isolat UPDH3, UPDH4, UPDH5, UPDH6 sensitif terhadap oksasilin dan isolat UPDH1, UPDH2, UPDH3, UPDH5 dan UPDH6 sensitif terhadap eritromisin dan ofloksasin. Pada uji antimikroba didapati zona hambat yang paling besar terhadap bakteri S.aureus oleh isolat UPDH1, UPDH2, dan UPDH5, serta zona hambat yang paling kecil terhadap bakteri E.coli. 


\section{UCAPAN TERIMA KASIH}

Ucapan terima kasih penulis ucapkan kepada Rektor Universitas Prima Indonesia, Dr Chrismis Novalinda, M.Kes, dan Dekan Fakultas Kedokteran dr Linda Chiuman, M.K.M yang telah memfasilitasi laboratorium sehingga penelitian ini dapat diselesaikan dengan baik. Ucapkan terima kasih juga disampaikan kepada pembimbing utama sekaligus kepada Lab Biologi Molekuler Fakultas Kedokteran, Bapak Edy Fachrial, S.Si., M.Si atas ide dan motivasi dalam penelitian ini, kepada tim analis laboratorium Biologi Molekuler Ditha Paramitha yang turut membantu dalam pelaksanaan penelitian.

\section{DAFTAR PUSTAKA}

Afriani, N., Yusmarini, Pato, U., 2017. Aktivitas Antimikroba Lactobacillus plantarum 1 yang Diisolasi dari Industri Pengolahan Pati Sagu terhadap Bakteri Patogen Escherichia coli FNCC-19 dan Staphylococcus aureus FNCC-15. J. Online Mhs. Fak. Pertan. Univ. Riau 4, 1-2.

Agustina, D., Mufida, D.C., A.S., H.R., Dharmawan, D.K., 2019. Uji Sensitivitas Antibiotik Terhadap Staphulococcus Aureus Yang Terdeteksi Dalam Sputum Pasien Dengan Pneumonia Yang Dirawat Di Rumah Sakit. J. Agromedicine Med. Sci. 5, 23. https://doi.org/10.19184/ams.v5i1.9267

Artati, Hurustiaty, Zulfian, A., 2016. Pola Resistensi Bakteri Staphylococcus sp Terhadap 5 Jenis Antibiotik pada Sampel Pus. Media Kesehat. Politek. Kesehat. Makassar XI, 63. https://doi.org/10.1017/CBO9781107415324.004

Fachrial, E., 2018. Aktivitas Antimikroba Dan Identifikasi Molekuler Bakteri Asam Laktat Yang Diisolasi Dari “ Pliek U ”, Makanan Fermentasi Tradisional Asal Aceh, Indonesia. SENSASI 82-85.

Ismail, Y.S., Yulvizar, C., Putriani, 2017. Isolasi, Karakterisasi dan Uji Aktivitas Antimikroba Bakteri Asam Laktat dari Fermentasi Biji Kakao (Theobroma cacao L.). Bioleuser 1, 52.

Kusmarwati, A., Arief, F.R., Haryati, S., 2014. Ekspolarasi Bakteriosin Dari Bakteri Asam Laktat Asal Rusip Dan Kalimantan. JPB Perikan. 9, 34.

Lintong, P.M., Kairupan, C.F., Sondakh, P.L.N., 2012. Gambaran Mikroskopik Ginjal Tikus Wistar (Rattus Norvegicus) Setelah Diinduksi Dengan Gentamisin. J. Biomedik 4, 186. https://doi.org/10.35790/jbm.4.3.2012.800

Nugraha, A., Besung, N.K., Mahatmi, H., 2013. Kepekaan Eschericia coli Patogen yang Diisolasi dari Babi Penderita Kolibasilosis terhadap Antibiotik di Kecamatan Kerambitan dan Tebanan Kabupaten Tabanan, Bali. J. Ilmu dan Kesehat. Hewan 1, 34-37.

Nur, F., Hafsan, Wahdiniar, A., 2015. Isolasi Bakteri Asam Laktat Berpotensi Probiotik Pada Dangke, Makanan Tradisional dari Susu Kerbau di Curio 
Kabupaten Enrekang. Biog. J. Ilm. Biol. 3, 60-62. https://doi.org/10.24252/bio.v3i1.568

Putri, A.A., Erina, Fakhrurrazi, 2018. Isolasi Bakteri Asam Laktat Genus Lactobacillus dari Feses Rusa Sambar (Cervus unicolor). Jimvet E-Issn: 2540-9492 2, 173.

Putri, Y.W., Putra, A.E., Utama, B.I., 2018. Identifikasi Dan Karakteristik Bakteri Asam Laktat Yang Diisolasi Dari Vagina Wanita Usia Subur. J. Kesehat. Andalas 7, 23.

Sidabutar, A.R., Feliatra, Dahliaty, A., 2013. Uji Aktifitas Antimikroba Bakteriosin dari Bakteri Probiotik yang Diisolasi dari Udangg Windu (Penaeus monodon Fabricus), J. Chem. Inf. Model 1, 8. https://doi.org/10.1017/CB09781107415324.004

Situmeang, S.M., Musthari, Riadi, S., 2017. Isolasi dan Uji Aktivitas Antimikroba Bakteri Asam Laktat (BAL) dari Yoghurt dalam Menghambat Pertumbuhan Bakteri Escheria coli dan Salmonella typhy. J. Biosains 3, 145148

Sunaryo, R., Martius, E., Marwoto, B., 2014. Uji Kemampuan Lactobacillus casei sebagai Agensia Probiotik. J. Bioteknol. Biosains Indones. 1, 9. https://doi.org/10.29122/jbbi.vlil.546

Ulfa, A., Kasih, A., Situmorang, F., Fachrial, E., 2019. Isolasi Bakteri ASam Laktat dari Makanan Tradisional Khas Batak "Naniura" dan Uji Sensitifitas terhadap Beberapa Antibiotik. SAINTEKS 163-164.

Urnemi, Syukur, S., Purwati, E., Ibrahim, S.,Jamsari, 2012. Potensi Bakteeri Asam Laktat sebagai Kandidat Probiotik Antimikroba Patogen Asal Fermentasi Kakoa Varietas Criollo. J. Teknol. Ind. 6, 68 \& 71. https://doi.org/10.14710/ijfst. 8.1.59-64

Yanti, D.I.W., Dali, F.A., 2013. Karakterisasi Bakteri Asam Laktat yang Diisolasi Selama Fermentasi Bakasang. J. Pengolah. Has. Perikanan. Indones. 16, 134. https://doi.org/10.17844 